\title{
RELATIONSHIPS BETWEEN MOLINA'S HOG NOSED SKUNKS, Conepatus chinga (Mammalia, Mephitidae) AND HUMAN BEINGS IN THE CHAUPIHUARANGA RIVER BASIN, PASCO, PERU
}

\section{RELACIONES ENTRE EL ZORRILLO Conepatus chinga (Mammalia, Mephitidae) Y EL SER HUMANO EN EL VALLE DEL RIO CHAUPIHUARANGA, PASCO, PERU}

\author{
E. Daniel Cossios $^{1 *}$, Fernando Valdez Ridoutt ${ }^{1}$ y Andrea Luna Donoso ${ }^{1}$
}

\begin{abstract}
Throughout the skunks' distribution range, several kinds of conflicts between these animals and human beings have been recorded. In Peru, although these issues seem to be common, records thereof have been merely anecdotal. Here we describe, for the first time, the relationships between people and skunks in a Peruvian area. The study was conducted in five villages of the Chaupihuaranga River basin, in Pasco department. Interviews were made to collect information about people's attitude toward Molina's hog-nosed skunks, the uses given to this animal, hunting methods and number of hunted skunks. Almost all interviewees $(97.8 \%)$ considered skunks as harmful animals and the majority (87\%) admitted hunting them. Skunks are mainly hunted to control the damage they cause to the crop fields, but they are also used as food, in traditional medicine and to make decorative elements. Two hunting modalities were reported: hunting following casual encounters and organized hunting by crop field keepers. The skunk skins are displayed at the homes of the hunting crew leaders, giving prestige to them. Genetic analyses performed on skin samples suggested stability or recent population growth. Both controlling skunk population to limit the damage they cause to the crop fields and using this species in traditional medicine seem to be ancestral activities. Although skunk hunting in the study area seems to be sustainable, we recommend conducting evaluations of skunk populations to verify whether hunting entails a risk factor for their conservation.
\end{abstract}

Key words: Conepatus chinga, Peru, people and wildlife conflicts, skunks, traditional medicine.

\section{Resumen}

Varios tipos de conflictos han sido registrados entre zorrillos y seres humanos. En el Perú, aunque tales problemas parecen ser comunes, los registros han sido solo anecdóticos. Aquí se describe, por primera vez, las relaciones entre la gente y los zorrillos en una localidad peruana. Se realizó entrevistas para colectar información sobre la actitud de la gente hacia los zorrillos, los usos dados a esos animales, métodos de caza y número de animales cazados en cinco pueblos del valle del río Chaupihuaranga, en el departamento de Pasco. Casi todos los entrevistados (97.8\%) consideraron nocivos a los zorrillos y la mayoría (87\%) admitió cazarlos. Los zorrillos son cazados principalmente para controlar el daño que causan en campos de cultivo pero también son consumidos como alimento, usados en medicina tradicional y para confeccionar objetos decorativos. Dos modalidades de caza fueron reportadas: caza tras encuentros fortuitos y caza organizada por parte de cuidadores de cultivos. Las pieles son expuestas en las casas de los líderes de cazadores, lo que les da prestigio. Análisis genéticos realizados sobre muestras de las pieles sugieren estabilidad poblacional o un reciente crecimiento. Tanto el control de las poblaciones de zorrillo para limitar los conflictos como el uso de esta especie en medicina tradicional parecen ser actividades ancestrales. Aunque la caza de zorrillos en el área estudiada parece ser sostenible, se recomienda evaluar su población para verificar si puede ser una amenaza hacia su conservación.

Palabras clave: Conepatus chinga, Perú, conflictos entre gente y fauna, zorrillo, medicina tradicional.

\section{Introduction.}

Skunks are common species, broadly distributed in the Americas. Throughout the area of distribution of this species, several conflicts between skunks and human populations have been recorded, including the transmission of rabies, destruction of apiaries, predation on bees, barnyard fowls and eggs, and damages to crop fields through their digging while 
looking for insects (Cerato \& Andelt, 2002; Dragoo, 2009).

Two skunk species are found in Peru (Pacheco et al., 2009): the Molina's hog-nosed skunk, Conepatus chinga (Molina, 1782), and the striped hog-nosed skunk, Conepatus semistriatus (Boddaert, 1785). The most common in Peru, the Molina's hog-nosed skunk, is considered locally common and out of danger but with declining populations (Emmons et al., 2016). Its maximum known longevity is 3 years and its generation time has been estimated at 3.6 years (Pacifici et al., 2013). The population density of this species is quite variable and has been estimated between 0.68 and 1.66 individuals $/ \mathrm{km}^{2}$ in Argentina (Castillo et al., 2011) and 5 individuals $/ \mathrm{km}^{2}$ in Chile (Cofré \& Marquet, 1999), but there are no estimates for Peru. The main threats to this species are the habitat loss due to the advance of agriculture, the presence of invasive species and hunting (Emmons et al 2016).

In the Peruvian Andes, damages caused by skunks to crop fields are a known fact (Deustua et al., 2008; Zeballos \& Carrera 2010), existing records about this problem since the seventeenth century (Guamán-Poma, 1615). Although conflicts between skunks and Andean farmers seem to be common, there are no studies about the relationships between skunks and human beings in Peru, or about traditional methods to control the damage caused by skunks in rural human communities. Nevertheless, information about the relationships between humans and wildlife is crucial for developing any management or conservation plan. Here we describe, for the first time, the conflicts between people and skunks in a group of Peruvian villages, the uses given to these animals and the way villagers organize skunk hunting sessions. In addition, we performed several tests, based on genetic methods, aimed at detecting signals of recent demographic changes in this skunk population.

\section{Methods.}

The Study Area.

The study was conducted in the villages of Tapuc, Rocco, Vilcabamba, Chacayán and San Pedro de Pillao, within the Chaupihuaranga River basin, in the Daniel Carrión Province, Department of Pasco, Peru (Figure 1; Table 1), throughout October 2010 and August 2011. This area was selected due to the previously known fact that some houses are decorated on the outside with Molina's hog nosed skunk skins, which evidences the hunting of these animals.

Interviews.

In order to obtain a description of the relationships between human beings and skunks, semi-structured interviews (Huntington, 2000) were conducted. All interviewees were adults. During the interviews, questions were asked about the attitude of interviewees toward the skunks, hunting reasons, hunting methods and periods, how hunting sessions are organized by

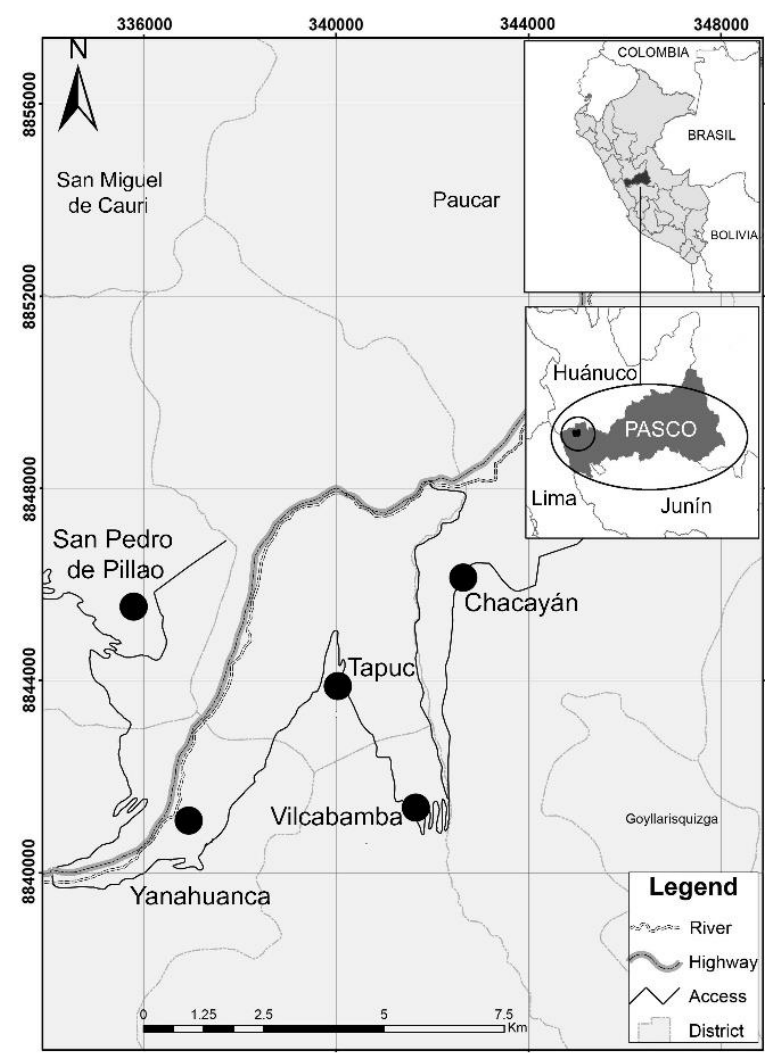

Figure 1. Map of the region where the study was conducted, showing the location of the five localities visited.

villagers and uses given to these animals. Also, we asked whether skunks are currently more or less abundant than in the past. In order to determine the number of hunted animals, skins kipped by the villagers were directly counted, whereas the skins of all the skunks hunted are exposed to the outside of the houses. Genetic and demographic analyses.

Twenty-three skunk skins were sampled in the Tapuc and Rocco villages and were genetically sequenced for three mitochondrial markers: Control Region, Cytb and COI. These DNA sequences were used here to perform demographic tests, which included Fu's test (Fu, 1997), mismatch distributions (Rogers \& Harpending, 1992) and the coalescent-based

Table 1. Places visited and interviewees sample make-up.

\begin{tabular}{|c|c|c|c|}
\hline \multirow[b]{2}{*}{ Locality } & \multicolumn{2}{|c|}{ Coordinates } & \multirow{2}{*}{$\frac{\sum_{0}^{0}}{\stackrel{0}{0}}$} \\
\hline & South & West & \\
\hline Tapuc & $10^{\circ} 27^{\prime} 17.8^{\prime \prime}$ & $76^{\circ} 27^{\prime} 42^{\prime \prime}$ & 30 \\
\hline Vilcabamba & $10^{\circ} 28^{\prime} 43.4^{\prime \prime}$ & $76^{\circ} 26^{\prime} 50^{\prime \prime}$ & 35 \\
\hline San Pedro de Pillao & $10^{\circ} 26^{\prime} 24^{\prime \prime}$ & $76^{\circ} 30^{\prime} 00^{\prime \prime}$ & 7 \\
\hline Rocco & $10^{\circ} 28^{\prime} 48^{\prime \prime}$ & $76^{\circ} 29^{\prime} 24^{\prime \prime}$ & 17 \\
\hline Chacayán & $10^{\circ} 23^{\prime} 18.8^{\prime \prime}$ & $76^{\circ} 16^{\prime} 58.8^{\prime}$, & 5 \\
\hline Total & & & 94 \\
\hline
\end{tabular}


Table 2. Differences in the organization of the authorities taking care of crop fields.

\begin{tabular}{|c|c|c|c|c|c|c|}
\hline Locality & $\begin{array}{l}\text { Positions } \\
\text { subordinated } \\
\text { to the field } \\
\text { mayor }\end{array}$ & $\begin{array}{l}\text { Field mayor's } \\
\text { gender }\end{array}$ & $\begin{array}{l}\text { Subordinates' } \\
\text { gender }\end{array}$ & $\begin{array}{l}\text { Subordinates } \\
\text { per field } \\
\text { mayor }\end{array}$ & $\begin{array}{c}\text { People per } \\
\text { group when } \\
\text { surveilling } \\
\text { the fields }\end{array}$ & $\begin{array}{l}\text { Positions } \\
\text { entitled to } \\
\text { exhibiting } \\
\text { skunk skins in } \\
\text { their homes }\end{array}$ \\
\hline Vilcabamba & $\begin{array}{l}\text { Alderman, } \\
\text { bailiff }\end{array}$ & Always male & Males & $5-7$ & $2-4$ & Mayor \\
\hline Tapuc & $\begin{array}{l}\text { Alderman } \\
\text { major, campo } \\
\text { minor, bailiff }\end{array}$ & Always male & $\begin{array}{l}\text { Males and } \\
\text { females }\end{array}$ & $6-7$ & $2-4$ & Mayor \\
\hline Rocco & $\begin{array}{l}\text { Alderman } \\
\text { major, field } \\
\text { alderman, } \\
\text { bailiff }\end{array}$ & No data & No data & $6-8$ & $2-6$ & $\begin{array}{l}\text { Mayor and } \\
\text { alderman }\end{array}$ \\
\hline Pillao & No data & $\begin{array}{l}\text { Male or } \\
\text { female }\end{array}$ & Males & $6-12$ & $2-6$ & Mayor \\
\hline Chacayán & No data & No data & No data & 6 & 2 & Mayor \\
\hline
\end{tabular}

Bayesian skyline plot analysis (Drummond et al., 2005). Fu's and mismatch distribution tests were performed in ARLEQUIN 3.5 (Excoffier \& Lsicher, 2010), while Bayesian skyline plot was performed with BEAST 1.7.1 (Drummond et al., 2002). For mismatch distributions, a bootstrap resampling of 1000 replicates was used to assess the fit to a model of sudden demographic expansion. The mismatch distribution test examines the frequency of the nucleotide differences between pairs of individuals in a population. A unimodal distribution is expected for a population that experienced a recent demographic expansion, while multimodal distributions are expected in populations at demographic equilibrium or decline (Rogers \& Harpending, 1992). Bayesian skyline plot uses coalescent theory to infer demographic changes through time. For this analysis, chains were run for 10 million generations and sampled every 1000 generations, and the initial $10 \%$ of the trees were discarded as burn-in.

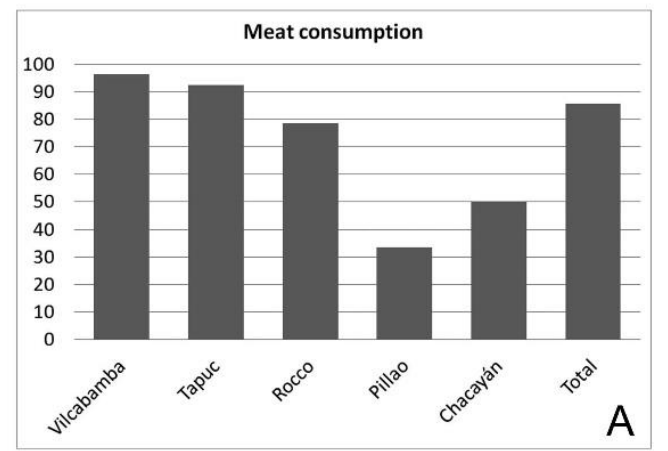

\section{Results.}

Perceptions and attitudes towards skunks.

A total of 94 people were interviewed (Table 1). Almost all the interviewees (91 persons, or 96.8\%) considered skunks as harmful animals for the following reasons: a) they damage the crop fields as they dig out searching for insects larvae $(95.7 \%)$, b) they consume the eggs of barnyard fowls as well as guinea pigs $(1.1 \%)$ and c) they are dangerous animals because their urine can render a person blind $(2.1 \%)$. Only three persons $(3.2 \%)$ stated that they do not cause any sort of problem. The great majority of the interviewees $(89.4 \%)$ declared hunting skunks to limit the damages caused by these animals. No other reasons to hunting skunks were reported.

All the interviewees said that skunks are common in the Chaupihuaranga valley. Nevertheless, 5\% of them stated that they are currently less abundant than ten years ago.

Uses.

Almost all interviewees (97.4\%) stated they use skunks for different purposes. Reported uses were: as food $(85.7 \%$ of interviewees, Figure $2 \mathrm{~A})$, to make

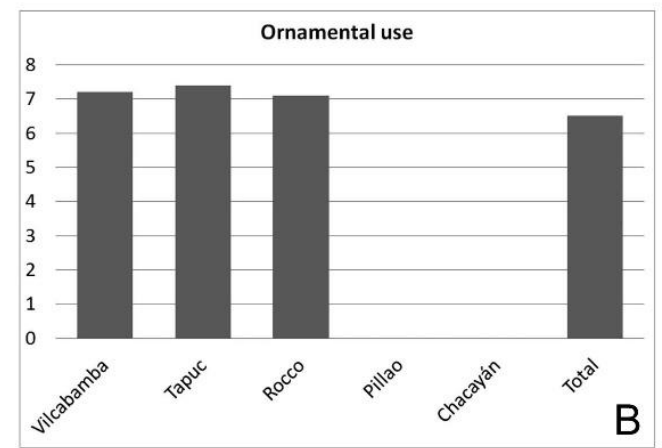

Figure 2. Meat consumption and ornamental use of skunks in the Chaupihuaranga River basin. The axis of ordinates of each chart shows the percentage rate of the interviewees who claimed to use skunks in a given way. 

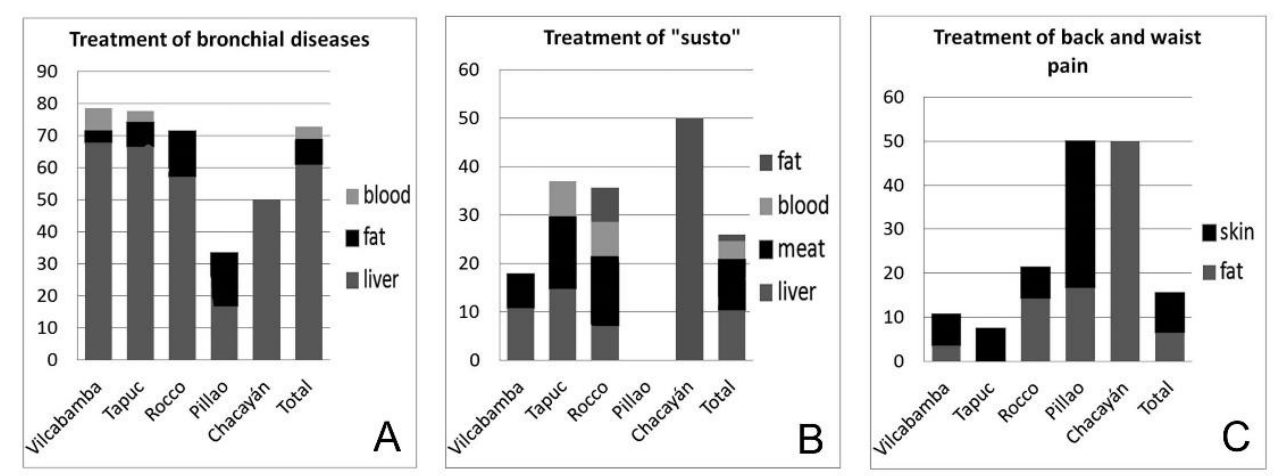

Figure 3. Medicinal use of skunks in the Chaupihuaranga River basin. Different colors depict the proportion in which the various parts of the skunk are used to treat ailments.

ornaments $(6.5 \%$, Figure $2 \mathrm{~B})$ and to prepare medicines (61\%, Figure 3). Two ways of preparing the animal for consumption were reported: the animal is stripped of its skin and fried $(85.7 \%$ of interviewees) or boiled in a soup $(9.1 \%)$. As a medicine, it is prepared in various ways: a) the skunk's liver is charred and a powder is obtained, which is then added into a hot infusion such as tea and chamomile to treat bronchial ailments $(80.5 \%)$, insolation $(1.1 \%)$ or to cure the susto disease $(6.5 \%)$ which, according to interviewees, is transmitted by supernatural beings called abuelos (the grandparents); b) the blood is consumed to treat epilepsy $(2.6 \%)$, susto $(3.9 \%)$, respiratory problems $(1.1 \%)$ or toothache $(1.1 \%)$; c) the fat is spread to fight against bronchial problems $(5.2 \%)$, to treat lower back pain $(6.5 \%)$ or to cure the scares $(1.1 \%)$; d) the meat, consumed as a soup, is used to cure respiratory problems (7.8\%); e) the skin is placed against the body to heal back pain, especially in the case of pregnant women $(5.2 \%)$ and $f$ ) the bile is used to cure circulatory problems $(1.1 \%)$. The use of skunk parts as ornaments is limited to the skin: some people hang them on an external wall of their home, as is it done by the leaders of the skunk hunting patrols, which are named field mayors (see the following section).

Hunting organization and methods.

We reported two kinds of skunk hunting: a) hunting after a casual encounter with a skunk, carried out by individual hunters, generally people who own a crop field or which works in one of them, and b) organized hunting sessions carried out by a group of hunters in order to take care of the crop fields of a whole village.

More than the half of interviewees $(56.3 \%)$ said they had hunted skunks after casual encounters. According to $100 \%$ of these people, this kind of hunting occurs at all times of the year and they claimed to have done it on their own, without the help of other people. To kill the animal, these hunters always knocked the skunk on the head with a stick or a stone. Sometimes they first threw and hit the skunk with a piece of dry cow dung in order to immobilize it before killing it.
$53.8 \%$ of interviewees stated they had participated in organized skunk hunting sessions. According to the informants, this kind of hunting is part of the activities of a group of people elected in each village to protect crop fields from any threat. Once a year, from the end of December to January $1^{\text {st }}$, a field mayor, called "alcalde de campo" or "alcaycampo", is elected. He, in turn, selects a number of subordinates. The field mayor will lead them in taking care of crop fields. In Tapuc and Vilcabamba villages, two field mayors are elected. Each of them is in charge of selecting their own subordinates and to take care of half of the crop fields of the village. Generally, the field mayor and his subordinates take office on January the first and hold the position for a full year. The number of subordinates and the names of the positions held by each of them vary among the villages visited (Table 2 ). The lowest ranked position is that of the bailiff, which is held by a boy, between five and nine years of age, whose main tasks are herding domestic animals and preparing the hunted skunks before cooking them. Both the mayors and their top subordinates are also called "campos" or "varayocs" and carry a cane or staff with them while they perform their surveillance role. The staff dignifies them as "varayocs", above other villagers, and is usually painted in a striking color (Figure 4A). "Varayocs" meet at the home of the field mayor whenever he deems necessary and plan the times and places where they will conduct the surveillance activities that will follow. Outings to take care of crop fields can be carried out at any time of the year, and at any time of the day, and the number of outings will depend on what the field mayor decides. "Varayocs" go out in groups, the size of which may vary among villages (Table 2). The care of the crops by varayocs includes expelling or detaining outsiders, capturing domestic animals that may be harming the crops and chasing away and hunting wild animals that are deemed harmful. Among the latter, interviewees named the Andean fox (Lycalopex culpaeus), parrots (Psittacidae Family) and other birds, opossums (Didelphis marsupialis) and skunks. 

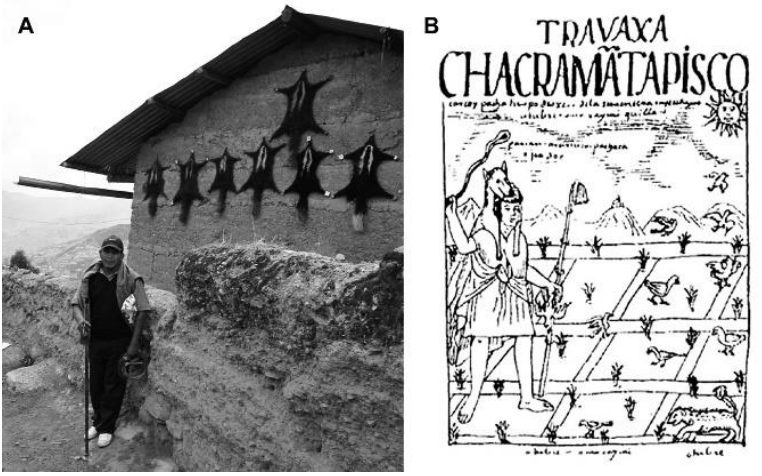

Figure 4. Examples of skunk control as an agricultural plague in Peru: A.- Field mayor of the village of Tapuc standing in front of the skunk skins hanging from his home's facade and holding a characteristic staff. B.Depiction of an ararihua or crop field keeper from the Incas Empire, taken from Guamán-Poma (1615).

According to interviewees, skunks have a special value to "varayocs", since skunks are nocturnal animals and hunting one proves that they have been working at night. Sometimes, nocturnal outings are carried out with the main goal of hunting skunks, mainly between January and March, and on full-moons, although this may be done at any time of the year. After hunting a skunk, the varayocs go to the field mayor's home, where they eat and drink to celebrate. They rip the hunted skunk off its skin and they hang the skin onto an external wall of the house. The skins are to remain there for years (according to one of the interviewees, the skins displayed at his home had been there for more than a decade) and point to the fact that the home owner has been important for the community (Figure 4A). In the village of Rocco, a mark is made on the long staff of the field mayor for each skunk that has been hunted. No confirmation could be made of whether this happens also in the other villages visited.

Number of hunted skunks.

In the five villages visited, we counted 58 skins of skunks hunted through the year 2009 and 68 skins corresponding to the year 2010 (Table 3). Three facts allow us to assure that the years assigned to the counted skins are correct: a) the varayocs change every year, so the skins shown in a house usually correspond to a

Table 3. Number of skunks hunted in each village visited. Numbers corresponds to the skins observed in the facades of houses, which come both from organized hunting and from individual hunting.

\begin{tabular}{lrr}
\hline Locality & \multicolumn{2}{c}{ Hunted skunks } \\
& 2009 & 2010 \\
\hline Vilcabamba & 23 & 21 \\
Tapuc & 19 & 22 \\
Rocco & 15 & 13 \\
Pillao & 0 & 12 \\
Chacayán & 1 & 0 \\
TOTAL & 58 & 68 \\
\hline
\end{tabular}

single year, b) the oldest skins change color by action of the sun, so it is easy to distinguish between old and newer skins, and c) both varayocs and some other people verified in each case to which year each group of skins corresponded. The percentage of these skunks that had been hunted by varayocs was of $75.4 \%$ (43 pieces) and $82.1 \%$ (46 pieces) for 2009 and 2010 respectively, while individual hunters had killed the remainder.

Genetic and demographic tests.

Fu's test showed a negative $F s$ value, but was statistically not significant $(F s=-1.63 ; \quad \mathrm{P}=0.19)$. Mismatch distribution was unimodal (Figure 5A) and the correspondent goodness of fit statistics was not significant, with low values of the sum of squared deviations $(0.01 ; \mathrm{P}=0.71)$ and raggedness index $(0.03$; $\mathrm{P}=0.79)$. In consequence, a fitting of the expansion model cannot be rejected.

BSP analysis indicated that the effective population size of Molina's hog-nosed skunk probably experienced a slight increase, but not drastic current changes (Figure 5B).
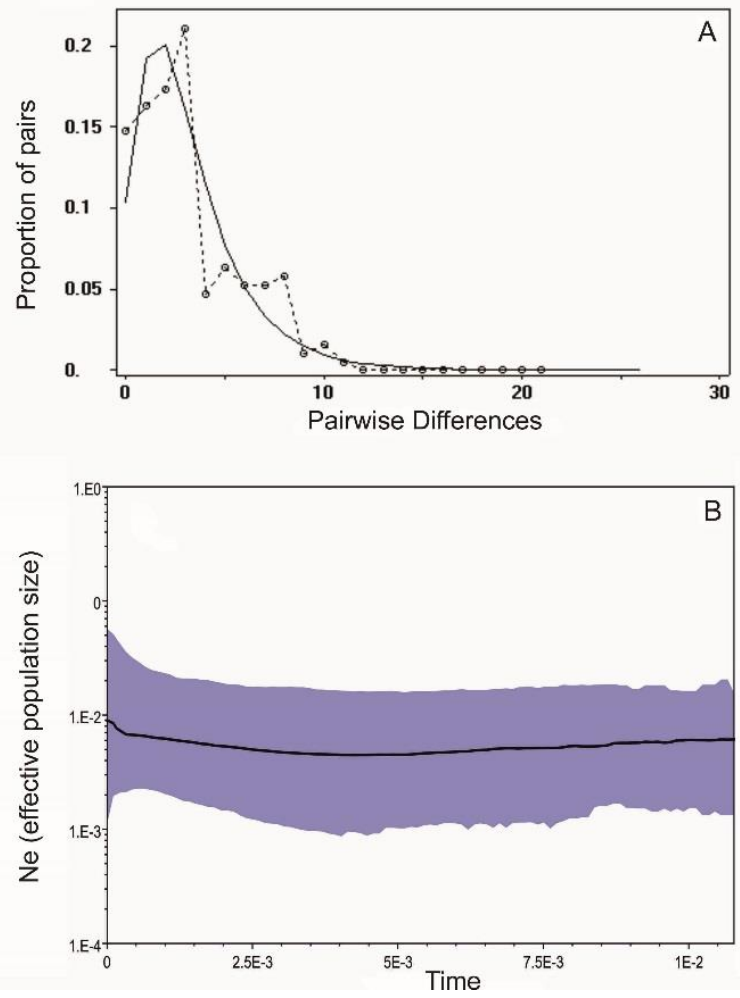

Figure 5. Demographic signals from the Molina's hognosed skunk genetic data from the Chaupihuaranga valley: A.- Mismatch distributions graphic. The dotted line corresponds to the observed frequency of pairwise differences while the continuous line represents a model under sudden demographic increase. B.Bayesian Skyline Plot, where $\mathrm{X}$-axis correspond to time, while $\mathrm{Y}$-axis correspond to mean effective population size. Blue-shaded areas encompass $95 \%$ highest posterior density (HPD). 


\section{Discussion.}

In Peru, wildlife hunting for direct consumption is allowed in farming communities such as the villages visited during this study. Given that the skunks hunted in the Chaupihuaranga River basin are consumed by the villagers, their hunting is legal.

Prior to the conquest of the Inca Empire by the Spaniards in the sixteenth century, Andean field keepers were called "ararihuas" or "parianes" and their tasks included controlling skunks and other animals that were considered a plague (Guamán-Poma, 1615) (Figure 4B). The "varayoc" position was created by the Spaniards between 1554 and 1580 to replace the ancient local chieftains called "curacas" or "caciques" (Vásquez, 1964). Nowadays, the organization of the farming community authorities in the Peruvian Andes varies according to the geographic location, and the designation of "varayoc" can be given to a single authority, generally the highest or most influential (e. g. in villages of the Cusco department), or to several authorities performing different roles which might include taking care of crop fields (e. g. in Huánuco and Ayacucho departments) (IIAP, 2006). The "varayocs" of the Chaupihuaranga valley keep similarities to ancient "ararihuas": in addition to taking care of the fields, "ararihuas" were also elected on a yearly basis (Arriaga, 1621) and among the objects that dignified them was a long staff (Guamán-Poma, 1615; Figure 4B).

In the rural areas of northwestern Argentina, less than $20 \%$ of people perceive skunks as harmful, and less than 5\% claim to hunt them (Lucherini \& Merino, 2008). Given that the most frequent problem caused by skunks seems to be the damage to crop fields, the difference between our results and those found in Argentina can be explained due to the economic activity developed in each site: in northwestern Argentina the main economic activity is livestock farming, while agriculture is the most important activity in the Chaupihuaranga valley.

The use of the skunk's roasted liver to fight against respiratory ailments has been reported in other locations, such as Ayacucho and Arequipa in Peru (Valdizán \& Maldonado, 1922), southwestern Bolivia and northwestern Argentina (Barbarán, 2004; Hernandez et al., 2015). Interestingly, all these places are currently inhabited by the Quechua ethnic group or have had a strong Quechua influence in the past, and no records of this custom were made in areas mainly occupied by the Aymara ethnic group, like centralwestern Bolivia and Puno, in Peru. This strongly suggests that the medicinal use of skunk liver has a Quechua origin. The use of fat to treat various pains is also much extended in the Andes. However, this is not limited to skunk's fat, but it also includes other carnivore species such as the puma, Puma concolor, the spectacled bear Tremarctos ornatus and the Andean fox Lycalopex culpaeus (Barbarán, 2004; Morales,
2010; Valdizán \& Maldonado, 1922; Zeballos \& Carrera, 2010). Consumption of Conepatus skunk meat as food has also been reported for the district of Ambo, in Ayacucho, Central Peru, although it is a less common practice there $(37.6 \%$ of interviewees) (Zeballos \& Carrera, 2010), and for Mexico (García-Flores et al., 2014) and Brazil (Luna de Oliveira et al., 2017). The use of skunk parts has been recorded in other places in Latin America to treat stomach ache, cryptorchidism, skin problems, anaemia, articular pain, nervous and circulatory system conditions, between other problems (Alves \& Alves, 2011; Enríquez et al., 2006; GarcíaFlores et al., 2014; Alves et al., 2016).

Several studies, carried out in Argentina and Chile, estimated the Molina's hog-nosed skunk population density between 0.68 and 5 individuals $/ \mathrm{km}^{2}$ (Emmons et al., 2016). Taking into account these estimations, the number of skunks hunted in the Chaupihuaranga valley would equal the population of $11.6-100 \mathrm{~km}^{2}$ per year. Although the population density in Peru could be very different, these data suggest that hunting could be a major threat to skunks and might indicate the need of creating a management plan for these animals. This idea is supported by the fact that some inhabitants of the study area said that skunks are less abundant than in the past. However, other data suggests that this perception might not be correct: a) the number of hunted skunks seems to be high, even when this is a traditional, very ancient activity, and skunk hunting take place only within crop fields, and b) demographic tests based on DNA sequences suggested stability or recent population growth. Given these contradictory data, a population assessment would be useful to determine if traditional hunting in the Chaupihuaranga valley is sustainable.

\section{Conclusions.}

In the Chaupihuaranga valley, the damage caused by skunks in crop fields is the main source of conflict between skunks and human beings, despite the fact that the control of insect populations by these animals can be beneficial for farmers when it is done outside of these lands. Other issues, such as egg consumption and the fear of skunks due to their urine may be considered unimportant for the conservation of skunks and for the wellbeing of human population.

Controlling the damage caused by skunks in the crop fields in Peru is part of an ancient activity that maintains some of its elements intact at least since the sixteenth century, such as appointing authorities on a yearly basis in order to take care of sown fields and the use of a long staff to dignify said authorities. Other elements, such as the number and the name of the keepers varies geographically, even among nearby villages. In the Chaupihuaranga valley, the exposure of hunted skunk skins plays an important role in giving prestige to the field keepers, which encourages hunting. 
The use of skunks in traditional medicine is common in Latin America, although the ailments treated, the skunk parts used as medicine and the treatments vary on a geographical basis. The treatment of respiratory conditions with roasted, ground skunk liver and the use of fat to ease various pains seem to be ancestral, since these customs are present in a significantly broad area of the Andean region: at least from Central Peru to the northwest of Argentina, in communities distributed throughout more than 1700 $\mathrm{km}$.

Although skunk populations do not seem to be at risk in the Chaupihuaranga valley, it is advisable to confirm this with population evaluations. Skunks are hunted because they are deemed harmful animals, but they are very appreciated as food and for their use in traditional medicine. Therefore, their conservation must be of interest for the rural population of the area studied. Should skunk populations be found which need protection, both conflicts and the use of this animal should be taken into account in order to create the corresponding management plans.

\section{Acknowledgments.}

We are grateful to Mr. Valerio Flores, Mr. Moisés Cristóbal and Mr. José Rivera for their help during the research. Our thanks to Slim Chraiti for making the map, to Claire Shea for improving a previous version of this manuscript and to Maritza Tovar for informing us about skunk hunting in Pasco. Daniel Cossíos was awarded a FQRNT scholarship while conducting this research. Finally, we would like to thank all the people who accepted being interviewed and those who guided us prior to and during field work.

\section{Literature Cited.}

Alves R.R.N., \& Alves H.N. 2011. The faunal drugstore: Animal-based remedies used in traditional medecines in Latin America. Journal of Ethnobiology and Ethnomedicine. 7: 9 .

Alves R.R.N., Feijó A., Duarte R.R., Silva W.M., FernandesFerreira H., Cordeiro-Estrela P. \& Langguth A. 2016. Game mammals of the caatinga biome. Ethnobiology and Conservation. 5:1-51.

Arriaga P.J. [1621]. 1920. Extirpación de idolatrías del Perú. Sanmartín, Lima, Perú.

Barbarán F.R. 2004. Usos mágicos, medicinales y rituales de la fauna en la Puna del Noroeste Argentino y Sur de Bolivia. Contribuciones al Manejo de la Vida Silvestre en Latinoamérica. 1: 1-26.

Castillo D.F., Lucherini M., Luengos Vidal E.M., Manfredi C. \& Casanave E.B. 2011. Spatial organization of Molina's Hog-nosed Skunk (Conepatus chinga) in two landscapes of the Pampas grassland of Argentina. Canadian Journal of Zoology. 89: 229-238.

Cerato M. \& Andelt W.F. 2002. Coping with skunks. Cooperative Extension Bulletin. Colorado State University. Natural Resources Series 6. 500: 1-4.
Cofré H. \& Marquet P.A. 1999. Conservation status, rarity, and geographic priorities for conservation of Chilean mammals: an assessment. Biological Conservation. 88: 53-68.

Deustua I., Williams M. \& Vásquez P. 2008. Relationships between human settlers and highland carnivores in the district of Anco, Center-South Peru. Ecología Aplicada. 7: 43-48.

Dragoo J.W. 2009. Family Mephitidae (Skunks). In: Wilson D.E. \& Mittermeier R. A. (editors). 2009. Handbook of the mammals of the world, vol 1: Carnivores, pp: 532562. Lynx Editions, Barcelona.

Drummond A.J., Nicholls G.K., Rodrigo A.G. \& Solomon W. 2002. Estimating mutation parameters, population history and genealogy simultaneously from temporally spaced sequence data. Genetics. 161: 1307-1320.

Drummond A.J., Rambaut A., Shapiro B. \& Pybus O.G. 2005. Bayesian coalescent inference of past population dynamics from molecular sequences. Molecular Biology and Evolution. 22: 1185-1192.

Emmons L., Schiaffini M \& Schipper J. 2016. Conepatus chinga. The IUCN Red List of Treatened Species 2016. eT41630A45210528. Consulted: November 26, 2018.

Enríquez P., Mariaca R., Retana O.G. \& Naranjo E.J. 2006. Uso medicinal de la fauna silvestre en los altos de Chiapas, México. Interciencia. 31: 491-499.

Excoffier L. \& Lsicher H.E. 2010. Arlequin suite ver. 3.5: a new series of programs to perform population genetics analyses under Linux and Windows. Molecular Ecology Resources 10:564-567.

Fu Y.X. 1997. Statistical tests of neutrality of mutations against population growth, hitchhiking and background selection. Genetics. 147: 915-925.

García-Flores A., Lozano-García M.A., Ortiz-Villaseñor A.L. \& Monroy-Martinez R. 2014. Uso de mamíferos silvestres por habitantes del Parque Nacional El Tepozteco, Morelos, México. Etnobiología. 12: 57-67.

Guamán Poma de Ayala F. [1615]. 1993. Nueva crónica y buen gobierno. Edited by F. Pease. Fondo de Cultura Económica, Lima, Peru.

Hernandez J., Campos C.M. \& Borghi C.E. 2015. Medicinal use of wild fauna by mestizo communities living near San Guillermo Biosphere Reserve (San Juan, Argentina). Journal of Ethnobiology and Ethnomedicine. 11: 15.

Huntington H.P. 2000. Using traditional ecological knowledge in science: methods and applications. Ecological Applications. 10: 1270-1274.

IIAP (Instituto de Investigación de la Amazonía Peruana). 2006. Conservación in situ de la agrobiodiversidad andino-amazónica 2: Organizaciones tradicionales. IIAP, Perú.

Lucherini M. \& Merino M.J. 2008. Perceptions of humancarnivore conflicts in the High Andes of Argentina. Mountain Research and Development. 28: 81-85. DOI: https://doi.org/10.1659/mrd.0903.

Luna de Oliveira W.S., Oliveira Luna M., Silva Souto W. \& Nóbrega Alves R.R. 2017. Interactions between people and game animals in a Brazilian semi-arid area. Indian Journal of Traditional Knowledge. 16: 221-228.

Morales V. 2010. Visión y conocimiento etnozoológico andino de la fauna silvestre: Municipio de Inquisivi, Bolivia. 2010. AGRUCO, Cochabamba, Bolivia. 
Pacheco V., Cadenillas R., Salas E., Tello C. \& Zeballos H. 2009. Diversidad y endemismo de los mamíferos del Perú. Revista Peruana de Biología. 16: 5-32.

Pacifici M., Santini L., DiMarco M., Baisero D., Francucci L., Grottolo G., Visconti P. \& Rondinini C. 2013. Generation length for mammals. Nature Conservation. 5: 87-94.

Rogers A.R. \& Harpending H. 1992. Population growth makes waves in the distribution of pairwise genetic differences. Molecular Biology and Evolution. 9: 552569.
Valdizán H. \& Maldonado A. 1922. La medicina popular peruana. Torres Aguirre, Lima Peru.

Vásquez M.C. 1964. The Varayoc system in Vicos. Cornell University Press, New York, NY.

Zeballos H. \& Carrera R.C. 2010. Mamíferos de la Reserva Nacional de Salinas y Aguada Blanca, Arequipa y Moquegua, suroeste del Perú. Páginas 249-259. En: H. Zeballos, J. A. Ochoa y E. López (editores). Diversidad Biológica de la Reserva Nacional de Salinas y Aguada Blanca. DESCO, PROFONANPE, SERNANP, Lima, Peru.

\footnotetext{
${ }^{1}$ Biosfera Consultores Ambientales. Calle Las Fresas 730, Miraflores, Lima, Peru.

* Autor de correspondencia: dcossios@yahoo.com.
} 